\title{
Empirical Examination of the Relationship Between Venture Capital Financing and the Profitability of the Portfolio Companies in Uganda
}

\author{
Ahmed Idi Kato ( $\sim$ ahmedkato2@gmail.com ) \\ University of South Africa Thabo Mbeki African Leadership Institute https://orcid.org/0000-0002-1811- \\ 6138

\section{Chiloane-Phetla E Germinah} \\ University of South Africa, College of Economic and Management Sciences Department of Applied \\ Management
}

\section{Research}

Keywords: Venture capital, VC-backed Small-Medium Enterprises, profitability, diversified- framework for Enterprise success, Uganda

Posted Date: March 30th, 2021

DOl: https://doi.org/10.21203/rs.3.rs-361403/v1

License: (c) (1) This work is licensed under a Creative Commons Attribution 4.0 International License. Read Full License

Version of Record: A version of this preprint was published at Journal of Innovation and Entrepreneurship on March 5th, 2022. See the published version at https://doi.org/10.1186/s13731-022-00216-5. 
Empirical examination of the relationship between Venture capital Financing and the profitability of the portfolio companies in Uganda

\section{By}

AHMED. I Kato

(1)

$\mathrm{Ph}$. D. Research Scholar

University of South Africa

Department of Applied Management system

College of Economic Management Sciences

School of Public and Operations Management

E-maail: ahmedkato2@gmail.com

\section{And}

Chiloane-Phetla. E Germinah

University of South Africa

Department of Applied Management system

College of Economic Management Sciences

School of Public and Operations Management

Department of Applied Management

E-mail: chiloge@unisa.ac.za 
List of Abbreviations

\begin{tabular}{|c|c|}
\hline BOD & Board of Directors \\
\hline DCs & Developed Countries \\
\hline DFIs & Direct Financial Institutions \\
\hline EAT & Earnings After Taxes \\
\hline EAVCA & East African Venture Capital Association \\
\hline EBIT & Earnings Before Interest and Taxes \\
\hline EU & European Union \\
\hline EVCA & European Private Equity and Venture Capital Association \\
\hline GDP & Gross Domestic Product \\
\hline GVCF & Government Venture Capital Fund \\
\hline IPOs & Initial Public Offers \\
\hline NDA & Non-Disclosure Agreement \\
\hline NVCA & National Venture Capital Association \\
\hline OECD & Organization for Economic Cooperation and Development \\
\hline PSFU & Private Sector Foundation \\
\hline ROA & Return on Assets \\
\hline $\mathrm{ROE}$ & Return on Equity \\
\hline SBIC & Small Business Investment Companies \\
\hline SMEs & Small -Medium Enterprises \\
\hline SPSS & Statistics Package for Social Sciences (SPSS). \\
\hline
\end{tabular}




\begin{tabular}{|l|l|}
\hline SVCA & South African Venture Capital Association (SVCA \\
\hline UIA & Uganda Investment Authority \\
\hline UNISA & University of South Africa \\
\hline URA & Uganda Revenue Authority \\
\hline USAID & United States \\
\hline USD & United States Agency for International Development \\
\hline USE & United State Dollar \\
\hline VC & Uganda Securities Exchange \\
\hline VC4A & Venture Capital \\
\hline
\end{tabular}




\begin{abstract}
Purpose

This paper empirically examined the relationship between Venture capital Financing and the profitability of portfolio companies in Uganda. Several empirical works paint an intriguing picture that $\mathrm{VC}$ financing is a reality in fostering economic growth of the early-stage enterprises

\section{Design/methodology/approach}

The paper embraced a mixed-method wherein quantitative data were collected from 68 key VC stakeholders and statistical data was analysed using a multiple regression model by generating the results from the SPSS. This was supplemented by 16 semi-structured face-to-face interviews. Qualitative data were transcribed and analysed using Altas-ti.

\title{
Findings
}

The key findings from this study suggest superior performance of VC-financed enterprises following $\mathrm{VC}$ financing when compared to non-VC financed enterprises. The VC-financed enterprises realised tremendous growth in terms of: Return on Equity - 42.3\%; profitability $30 \%-50 \%$; Return on Assets - 44.5\%. In addition, $63 \%$ of the respondents confirmed a positive impact of government regulatory policy in enhancing the development of the early-stage firms. The higher the percentage of growth the better for the growth of the company.

\section{Research limitations/implications}

This study may assist the policymakers and business fraternity to develop policy frameworks tailored to enhancing a vibrant venture capital market in Uganda.

\section{Contribution/value-add}

This study makes a vital contribution to knowledge by offering a diversified framework for enterprise success, to benefit the VC stakeholders in customizing funding programs that can propel the early-stage enterprise success in Uganda and similar emerging economies. 
Keywords: Venture capital, VC-backed Small-Medium Enterprises, profitability, diversifiedframework for Enterprise success, Uganda.

\section{Introduction}

Small- Medium Enterprises (SMEs) have been hailed globally for their enormous contribution to GDP, economic development and employment creation (Mason 2009; Beck \& Cull 2014; Shanthi \& Schneider 2018). SMEs in the emerging nations including Uganda have continued to suffer from finance deficiency for their survival and growth (Divakaran, Mcginnis and Shariff, 2016; Turyahikayo, 2015; Ayyagari, Demirgüç-Kunt \& Maksimovic, 2017; Esho and Verhoef, 2018) regardless of their economic implication. While SMEs struggle to seek external bank financing, financial intermediaries are frequently unwilling to provide them bank mortgages because they are recognized as high-risk investment ventures (Berger \& Udell, 1998; Ernst \& Young 2016; EU/OECD, 2016). Topical literature discloses that if the developing countries are to escalate the success of the SME sector, access to sustainable funding is fundamental for their development (Beck and Demirgüc-Kunt, 2010; Turyahikayo, 2015; Eniola \& Ektebang, 2014). Consequently, numerous scholars have struggled to analyse and understand this sector, while the practitioners make every effort possible to create a supportive investment environment but these efforts have been uncoordinated and their results remain unnoticed.

In light of these malfunctions, $\mathrm{VC}$ financing $(\mathrm{VC})$ emerged as the best suitable funding model for early-stage enterprises development to benefit the "missing middle" parallel to bank loans (Hisrich, \& Polonchek, 1998; Hellmann \& Puri 2002; Cumming \&Johan, 2009; Bertoni \& Tykvova, 2015; (Bertoni, Colombo, \& Quas, 2015). To this end, empirical evidence confirms that VC financing primarily assists to close the routine funding deficiencies for the early-stage 
enterprises and rapidly enhances their growth (Gompers, Kaplan \& Mukharlyamov, 2015; (Ueda and Hirukawa, 2008; NVCA, 2004; HIS Global Insight, 2008; Li and Zahra 2012; Breuer and Pinkwart, 2018; Monitor Group and SAVCA. (2011). In addition, research has uncovered that on average the VC-funded companies exhibited superior performance matched to the non VC-funded companies. For that reason, VC financing is increasingly drawing attention for its vital contribution to employment creation, GDP development and a driver for innovation (NVCA, 2009; IHS Global Insight, 2008; Bocken, 2015; Gompers and Lerner, 1998; Murray, 2007; Metrick and Yasuda, 2010). However, the VC financing model is a size that does not fit all, the Venture Capitalists (VCs) only select companies that have already demonstrated growth potential. As such a few start-up firms qualify owing to the rigorous due diligence system. This has left several questions unanswered. The key question to ask is "Does $V C$ investment into the early-stage enterprises contribute to their success and growth? Previous scholarships offer inadequate conclusions to account for the difference in performance and these studies focused mainly on the developed economies (Jain and Kini 1995, Bottazzi, Da Rin \& Hellmann (2008).

Scholarly evidence certifies that many of the countries which have been successful in the VC market like the US, Canada and Israel, were highly reinforced by government funding (Lerner, 2010; Bertoni \& Tykvova, nonetheless, some scholars explain that government-owned VC funding schemes have been largely unsuccessful to engender justifiable conclusions (Cumming, Grilli \& Murtinu, 2013; Munari \& Toschi, 2015). For that reason, the commonly known hybrid funds succeeded government-owned VC funding method, where government Co-finances with the private VC firms to intensify VC market development. Although the VC gauge has been exceptionally tagged to the US which by far is the leader in the VC industry, recently numerous countries are beginning to tap into the possibilities that venture-backed 
companies can offer (HIS Global insight, 2008). However, they have remained unclear about the suitable policy frameworks to undertake (Lerner, 2010), and considerable misapprehensions about this financial intermediary remains a big problem.

Recent research also discloses that VC financing has been under-researched in the emerging countries, inadequate evidence is available to acknowledge its subsequent impact on the growth of small firms (Kenawy and Ghany, 2012; Divakaran et al., 2014; Shanthi, McGinnis, Schneider, 2018). Concisely, the contribution of VC financing on the profitability of the VCfinanced enterprises has not been extensively deliberated among scholars. Ekanem, Owen and Cardoso, (2019) observe that VCs transplanted the Silicon Valley model to emerging markets without making meticulous adjustments to reflect their business environment needs. This VC myopia has been identified to hamper SMEs' growth.

This paper, therefore, reviews the current literature to identify existing gaps in our current understanding of $\mathrm{VC}$ financing. By doing so, the paper addresses two fundamental research questions: First, "Does venture capital financing spur the profitability growth of the portfolio companies?" Secondly, the paper further interrogates "How does the presence of the venture capitalists on the BOD of the portfolio companies influence enterprises success?"

These hypotheses and the associated primary evidence need to be tested by laborious analysis of the deductions of the present literature and judiciously considered and performed comparisons. This may benefit the Venture Capitalists (VCs) in their efforts to make ideal investment decisions and also help the experts and government in making suitable regulatory policies to enhance VC market development. 
Previous studies have mainly concentrated on measuring the impact of VC financing on SME's performance using ordinary financial performance variables (Memba, 2011; Nkwame, 2017; Biney, 2018). No study has developed a diversified framework for enterprise success. Therefore this study makes a vital contribution to knowledge by offering a diversified framework for enterprise success in emerging economies with emphasis to Uganda The framework may benefit the key players in the VC market to evaluate and customize sufficient funding programs that can propel early-stage firms' success. This framework is strengthened with empirical findings from this study and literature evidence that underpins the capacity of VC finance in stimulating SMEs' success. The paper also delivers topical studies, several of which have not been encompassed in previous studies. This paper is organized in six sections, encompassing, a literature review, research methodology, data analysis and findings, research limitations/future research directions, contribution to knowledge and conclusion and recommendations. The following section discusses the theoretical perspective of VC financing.

\section{The theoretical perspective of Venture capital financing.}

In this section, we deliver a detailed stocktake of extant literature works by prior scholars which underwrite the contribution of $\mathrm{VC}$ finance on the profitability of the $\mathrm{VC}$-financed enterprises to inform and illustrate our thoughts. Our barometer also diagnoses the role of VCs on the BOD of the portfolio companies in supporting enterprises' success. The paper primarily describes the central concepts of $\mathrm{VC}$ and theoretical framework underlining the influence of $\mathrm{VC}$ on the profitability of the investee companies which is worthwhile to provide a foundation for the study. In the next sub-section, we discuss how VC financing contributes to the profitability of VC-financed enterprises with empirical evidence from recent studies. 
Notwithstanding the mounting studies about VC financing, scholars offer conflicting conclusions about the best approach to develop the VC markets (Lerner, 2010; Tykvova, 2018). Earlier studies have encapsulated that early-stage firms that have embraced VC financing mechanisms are much more innovative than their counterparts the non VC-financed companies. Particularly they are characterized by faster growth, attract superior human capital which improves their productivity, easily get their products to the market, and have greater opportunities for internalization (Hellman and Puri, 2002). On the contrary, Bottazzi et al., 2008 do not concur with the later authors. They surveyed 511 companies listed on Europe's securities financial markets but the results exposed that VC-financed enterprises did do not generate more sales revenue and employment growth matched to the non VC-financed enterprises in the same sector. This paper attempts to identify such existing gaps and problems and provide a future research direction that may help researchers to obtain a better understanding of the VC market operations in the context of the developing countries.

\subsection{Venture capital and profitability growth of the portfolio Companies}

There is empirical evidence to suggest that VC financing is connected with a quicker firm's growth and a precursor for innovation and internationalization of the portfolio companies (Kelly \& Hankook, 2013). Whereas there are other reasons for starting a commercial enterprise, profit maximization is the primary objective (Kenawy and Ghany, 2012). In any one's knowledge, early-stage enterprises certainly must earn profits to attract patient capital to promise their continued commercial growth and expansion over time. Several Researchers majorly from technologically advanced economies have confirmed that $\mathrm{VC}$ finance is a reality in augmenting the growth of SMEs. (Gompers \& Lerner, 1998; Deloitte \& NVCA, 2009; Lerner, 2012). Albeit VC finance has been extensively studied, its subsequent impact on the 
profitability of the portfolio companies has been comparatively underexplored. (Agyeman, 2010; Divakaran et al., 2014; Antarciuc et al., 2018).

One of the very first studies assessing VC-financed enterprises' performance, was piloted by the Venture Economics Incorporation for the US General Accounting Office in 1982. The study disclosed that VC-backed companies realized tremendous growth in sales turnover, employment creation, and tax payments matched to other companies. As a result, the success of the US VC market glimmered numerous empirical studies carried out by academics and policymakers to examine the economic impact of $\mathrm{VC}$ in boosting start-up firms. In line with the benefits of VC financing, the NVCA-National Venture Capital Association, (2009) discovered that the VC-backed companies grew faster than their national industry counterparts in terms of employment, sales, and wages. Similar results were also obtained in Europe (EVCA 2003). Where the venture-backed companies achieved a yearly sales growth of $35 \%$ as compared to $14 \%$ of other associated European public firms and employment grew $30.5 \%$ (Achleitner and Klockner, 2005). All these findings vehemently support the role of VC financing in spurring the growth of small firms.

A recent study of (Mason 2009; Kenawy \& Ghany, 2012) unveils that VC financing is the most suitable financial intermediary for the success and growth of the early-stage enterprises since SMEs are underprivileged without collaterals to offer to access conventional banking lending. The striking results have been detected in economic growth and high labour productivity of the VC-financed enterprises We also find prior research demonstrates that SMEs in the industrialized nations have averted the hitches of funding accessibility due the use of modern VC financing technologies in the market (Lerner, 2010; Baldock \& North, 2015; Gompers et al., 2015). Furthermore, VCs empowers start-up firms to handover the financial risk in the case 
of business failure to the investor companies. In return, the VCs forfeit a percentage of their equity returns on a potential exit of their venture. Besides, they nurture SMEs and ensure that they yield high returns on invested capital benchmarked between 15\%-30\%. The major goal of the VCs is to reap high returns from their high-risk VC investments (Tykvova, 2018) However, Tarek, (2003) argued profitable investment ventures are often highly associated with financial risks for which VC finance stands in as shock observer for such business uncertainties.

Kelly \& Hankook, 2013 and Paglia \& Harjoto, (2014) inspected the performance of the VCfinanced enterprises using measurable proxies like employment, sales turnover, and profitability. Their findings unveil that VC financing positively influences the VC-funded companies' profitability growth. However extant finance literature underpinning the role of $\mathrm{VC}$ on the performance of early-stage enterprises especially in the emerging economies like Uganda, remain fragmented. Previous studies highlight a positive impact of VC finance on SMEs' performance, exhibited in job creation and sales turnover (Bertoni et al., 2018; Chemmanur, Krishnan and Nandi, 2011; Cumming et al., 2013; Paglia \& Harjoto, 2014). A handful of earlier studies have investigated the contribution of VC finance on the profitability enhancement of the portfolio companies. This ignited a further study of this kind to accentuate the critical role played $\mathrm{VC}$ in enhancing the profitability of the investee companies.

Puri \& Zarutskie, (2012) observe that whereas VC-financed enterprises grow faster and trade on a large scale, they are less profitable at the level of IPOs or trade sales parallel to the non VC-financed enterprises. Harris et al, (2014) reported similar results where he concluded that the majority of the VC investment in the 2000s delivered unsatisfactory results in terms of returns on invested capital. While Jaki and Molnar, (2017) asserted that profitability growth 
changes progressively in an early-stage of 3 to 5 years, and subsequently a decline is recognized when the VCs plan to exit.

Earlier research of (Kwame, 2017; Serrasqueiro, Nunes \& Armada, 2016) uncovered that the VC-backed companies realized increased market expansion and profitability subsequent VC financing. This study is consistent with the previous findings of Carvalho, Netto \& Sampaio, (2013) who revealed higher profitability and sales growth of the PE/VC financed companies in Brazil equated to non PE/VC-backed firms in the first 3 years after the IPO. To conclude, we find that there is evidence to support that there is a positive relationship between VC finance and profitability of the VC funded- companies.

\section{Role of venture capitalists on the BOD and Enterprise success.}

Numerous studies have documented that the VCs involvement on the BOD is fundamental for the success and growth of the VC-financed companies. The vital contribution of the VCs has been repeatedly mentioned in the sphere of Value-added to the portfolio companies, (Hellmann, Puri 2002; Bertoni \& Tykvova, 2015). The recent study of Gompers et al, (2020) discovers that the VCs benefit the VC-funded firms as they support them to gain credibility and increase their opportunities to access new investors. These findings conflict the earlier conclusions of Gompers \& Lerner, 1998 presented the VC-backed industries are characterized by a potential conflict of interests that may compel the VCs to grandstand portfolio companies for IPOs or trade sale. This study was extend by Tykvova, 2018 who alluded that the VCs are reap high returns on their $\mathrm{VC}$ investments, promoting the growth of the portfolio companies are peripheral to their commercial agenda. These mixed reactions necessitated additional research in this field to partially fill these gaps with a new dataset. 
Gompers and Lerner, 1998; Lerner, 2010; Gompers, 2020) report VCs not only provide VC funds but also secure minority seats on the BOD to oversee their investments but provide managerial advice, detect financial risks of the companies at an early-stage, undoubtedly close the knowledge gaps, and manage the volatile markets. They also enter into VC contracts with the entrepreneurs in a way to deal with the moral hazards and information asymmetries (Gompers, 1999; Hellmann \& Puri, 2002). Besides, VCs come along with technological transfers coupled with human capital superior skills that would otherwise be inaccessibility without their buoyant presence on the BOD. These strategic partnerships augment the success and growth of the portfolio companies compared to other companies.

Surprisingly, while several authors elevate the VCs for their growing involvement in the portfolio companies, Aldrich, 2008; Lee and Wahal (2004) disclose VC financing is not for mediocre companies nor designated for all commercial sectors. To sustain above argument, VC financing is not a size that fits all because it only benefits a small number of the early-stage enterprises due to the rigorous due diligence exercise whereby on average 2 out 100 potential SMEs applicants qualify for VC funding (NVCA, 2009; Gompers et al., 2004). The worst scenario VC investors target specific industries, for instance, high-tech industries and concentrate in a few regions globally such as the US, Canada, Europe, and China among others. To strengthen this debate, supported by the high- technological internet companies like Google, YouTube, Microsoft, and Yahoo which were once VC funded (Gompers, 1995; Roberts and Barley, 2004; Zacharakis et al., 2007; Deloitte \& NVCA, 2009) concentrated in the US. We can, therefore, conclude that generally, VC finance evolved not necessarily to take care of the financial needs of all SMEs but largely to the technological internet companies as mentioned 
In conclusion, prior literature confirms that VC financing stimulates the growth of start-up firms and is a sustainable solution for averting the problem of lack of access to external financing (Gompers \& Lerner, 1998; Chemmanur et al., 2011; Biney, 20018; Tykvova; 2018). However, there is little evidence to document VC performance in emerging countries like Uganda. (UIA, 2016). VC finance is a financial intermediary with the capability to stimulate the VC backed firms' SMEs' growth conveyed in increased sales revenue, growth in ROE, profitability growth, and ROA. The literature review offered a firm foundation to craft the research questions. The rest of the paper is organized as follows. The first section combines a literature review with theory and concept development. This is followed, respectively, by a discussion of the research methodology and the main results. The final section provides implications, a summary, conclusions, and suggestions for future research.

\section{Research design/Method}

The study adopted a mixed-method which involves both the quantitative and qualitative research methods (Creswell \& Plano Clark 2010). Given that VC financing is new and underdeveloped in Uganda, this research technique was found suitable because it provides the researcher with an opportunity for a more complete and comprehensive understanding of the research problem (Saunders, Lewis and Thornhill, 2012). The quantitative method was more predominant, and it as augmented by interview qualitative data given that the study mainly used financial performance variables.

\subsection{Population/sampling/data collection}

The primary source of data was the UIA's database comprising SMEs classified as the topperforming SMEs in 2018 and 2019. Given that the UIA's database did not maintain a segregated catalogue for the VC-backed firms, we also used the profiles of active VC firms in 
Uganda to track their portfolio companies. The stratified random sampling was applied to obtain a sample size of 90 respondents from a total population of 300 SMEs. Furthermore, we purposively selected 30 interviewees $(S=10 \%$ of 300$)$ for the semi-structured face-to-face interviews involving entrepreneurs/senior managers, VC firms, government agencies, and SME association representatives. These categories were chosen because they compose the highest decision-making body of SMEs inclined with a wealth of knowledge and custodians of data required for the study (Gompers \& Lerner, 2004). Our sample respondents were selected from the central business districts with the highest concentration of SMEs situated in the Kampala, Wakiso, Mukono, and Jinja districts. Besides, the study focused on two sectors, the manufacturing sector was preferred as it contributed $21.6 \%$ to the total national revenue collections than the fast-moving consumer goods sector, while agribusiness makes up $67 \%$ of Uganda's economy (URA 2018). In Table 3.1, we illustrate the composition of our research sample size.

Table 4.1. Composition of the Sample Size for survey research

\begin{tabular}{|l|l|l|}
\hline Targeted category & Sample Size & $\%$ of Sample \\
\hline Non VC backed SMEs & 36 & $40 \%$ \\
\hline VC backed SMEs & 44 & $49 \%$ \\
\hline VC Firms & 6 & $7 \%$ \\
\hline Government Agencies & 2 & $2 \%$ \\
\hline SME Associations & 2 & $2 \%$ \\
\hline Total & 90 & $100 \%$ \\
\hline
\end{tabular}

Source: (Primary data, 2019-2020)

Table 3.1 indicates the VC backed firms and non VC-backed firms contributed a higher percentage of $89 \%$ combined, because the major aim is to measure the SMEs' performance after VC financing matched to the non VC-backed firms. While government agencies, VC 
firms, and SMEs associations were included as they play a critical role which may determine the direction of SMEs' performance.

\subsection{Quantitative data collection}

Primary data was collected using a 5 Likert scale semi-structured questionnaires administered to 90 key informants experts as mentioned in the above section. This data collection instrument was ostensibly identified and acknowledged for saving time, mitigating the hustle of crossexamining and recording the participants' rejoinders, as well as handling numerous topics and analysis of data (Collins \& Hussey 2009). It also offered the respondents an opportunity to complete the questions at their convenience, since they comprised a customarily busy class. The survey questionnaire involved multiple questions ranging from strongly disagree (1) to strongly agree (5) and an average score for agreeing $\geq 3.5$. Out of the 90 questionnaires administered, 70 were returned and the 2 were found not suitable for data analysis because they contained fundamental omission of required data.

\subsection{Measurement of performance Variables}

To measure the interdependence between VC finance and the performance variables (ROE, Sales turnover and net income), we use a multiple regression model wherein VC finance and profitability are designated as independent and dependent variables respectively. We extracted data from the 68 survey questionnaires, this was organised in excel worksheet thereafter exported to SPSS computer-aided program to run the results. This program is trusted by several scholars because it has inbuilt formulae which compute inferential and descriptive results. We also computed the sales turnover, ROE, and net income using the ratio analysis with the assistance of the audited and unaudited reports probed by the respondents. 
Out of the 90 questionnaires administered, 70 were returned, 2 were found not suitable for data analysis because they contained fundamental omission of required data. We, therefore, found 68 completed and returned questionnaires apposite for data analysis. This produced a response rate of $76 \%$, higher than the comparative study of Memba, (2011) which had a response rate of $65 \%$ (65 out of 100). These results are supported by Mundy, (2002) who discloses that the higher the response rate the better, $60 \%$ would be marginal, $70 \%$ is reasonable, $80 \%$ would be good, and $90 \%$ would be excellent. As such, there is no justification not to accept a response rate of $76 \%$, because it conveys reliable and valid results, representative of the entire population under study. To evaluate the VC financing impact on the profitability growth of the portfolio companies, we run several inferential tests using a multiple regression model as illustrated below. The independent variables are $\mathrm{VC}$ and the dependent variables are profitability measured by sales turnover, EBIT and ROE.

The Multiple Linear Regression model is illustrated as:

$\mathrm{yj}=\beta 0+\beta 1 X_{j 1}+\beta 2 X_{j 2}+\ldots+\beta \mathrm{k} X_{j k}+\varepsilon \mathrm{j} \quad$ Equation (1)

$\mathrm{y}$ is the Firm's performance (Sales. ROE, ROA, Profitability, Government Regulations)

$\beta 0$ is the $\mathrm{y}$-intercept wherein the value of y when $X_{j 1}, X_{j 2} \ldots \ldots X_{j k}$ are equal to 0 .

$\beta 1$ and $\beta 2$ are the regression coefficients that represent the change in y relative to a one-unit change in $X_{j 1}, X_{j 2} \ldots \ldots X_{j k}$, respectively.

$\mathrm{Bk}$ is the slope coefficient for each independent variable

$X_{1}=$ Venture capital Finance as one of the independent variable

$X_{2}=$ Venture Capital Involvements on the BOD as the second independent variable

$€ \mathrm{j}$ is the model's random error (residual) term

The predictor variables are specified as a $\mathrm{j}$ and $\mathrm{k}$ matrix, where $\mathrm{j}$ is the number of observations, while $\mathrm{k}$ is the number of predictor variables. For each column of $X$ denotes one independent variable, and each row represents one observation, while $y$ is the response for the corresponding row of $X$. 
The VC-backed companies and non-VC backed companies are binary variables that were allocated 1 to indicate they received VC financing and 0 , if they did not receive VC financing. To confirm the research questionnaire for validity and reliability, Alpha Cronbach's coefficient was applied to test the results, with a 95\% significant confidence level and a 5\% margin of error. The results showed a $98.4 \%$ confidence level of the survey questionnaire and a margin of error of $1.6 \%$ which was much lower than an estimated $5 \%$. The statistical tests relied on the two-sided tests represented as 0.05 level of significance.

\subsection{Semi-structured Face-face interviews}

Semi-structured interviews create a forum for free responses that allow the respondents to provide detailed information and clarity on the research problem which a survey questionnaire may not be able to incarcerate (Bryman, 2012). Qualitative data were collected from 16 faceto-face interview proceedings out of the 30 earlier prearranged with the VC experts, believed to have diverse knowledge about the study. The same respondents identified for statistical data were equally engaged for qualitative interview data collection. Previous studies have mainly engaged business entrepreneurs and management staff as key respondents (Jagongo, 2012; Biney, 2018). However, this paper is unique in a way that conveys the thoughts of the different players in the VC market which have not been reported in earlier scholarships. The qualitative data gathered from the recorded face-to-face interviews, videos, audited accounts, financial reports, narrative reports, and researcher's observations were transcribed, reviewed, and later exported to Atlas- ti version 25.

We generated memos, groups, and networking linkages which facilitated a coherent content analysis of data. Thereafter, data was validated and triangulation was performed until a point of saturation was attained at the 16 interviewees. The study found the 16 audio recorded 
interviews sufficient by trusting the saturation concepts. Responses from the interviewees at this stage were producing similar results not different from the earlier interviewed respondents. To reinforce our results, Saunders, Lewis and Thornhill, (2009) argues that when the point of saturation is attained, the results are adequate as a true representation of the sample. While O'Reilly, (2013) reveals that a point of saturation is reached when the researcher does not gain any new information different from the earlier findings. However, data collection from semistructured interviews is non-standardized, questionnaires and procedures may change in the course of the research process. This triangulation interview method has the advantage to aggregate in-depth interviews with secondary data that offers a considerable understanding of the research problem (Creswell, 2003).

\subsection{Ethical consideration}

The study received approval from the Research Ethical clearance committee of the University of South Africa (UNISA) in August 2019. We also received prior approval from UIA and USSIA to access to their databases. We further obtained prior consent from all the respondents before commencing the study who sign informed consent as confirmation for their involvement in the study. We signed Non-Disclosure Agreements (NDA) not to share any information to any third parties without prior management approval. The respondents had the liberty to decline to respond to some of the questions they found disturbing or they perceived uncomfortable.

\section{Data analysis and discussion of results}

We use the performance variables involving ROE, ROA and EBIT as the dependent variables, while the presence of the VCS on the BOD and VC finance represents the independent variable. This section is organised following the research questions. We start by discussing the contribution of $\mathrm{VC}$ financing on the profitability growth of the portfolio companies. 


\subsection{Hypothesis 1: Contribution of $\mathrm{VC}$ financing contributes to profitability growth of}

the portfolio companies.

We use financial ratios to compute the Earnings before Interest \& Tax (EBIT) for both the VCbacked firms and non VC-backed firms covering a period of 3 years (2016-2018). Data were extracted from the audited and unaudited financial statements. This data was validated comparing it with figures extracted from the survey questionnaires. 
Figure 1. Comparison of Profits before Interest and Tax for the VC-backed and non VCbacked firms from 2016 to 2018.

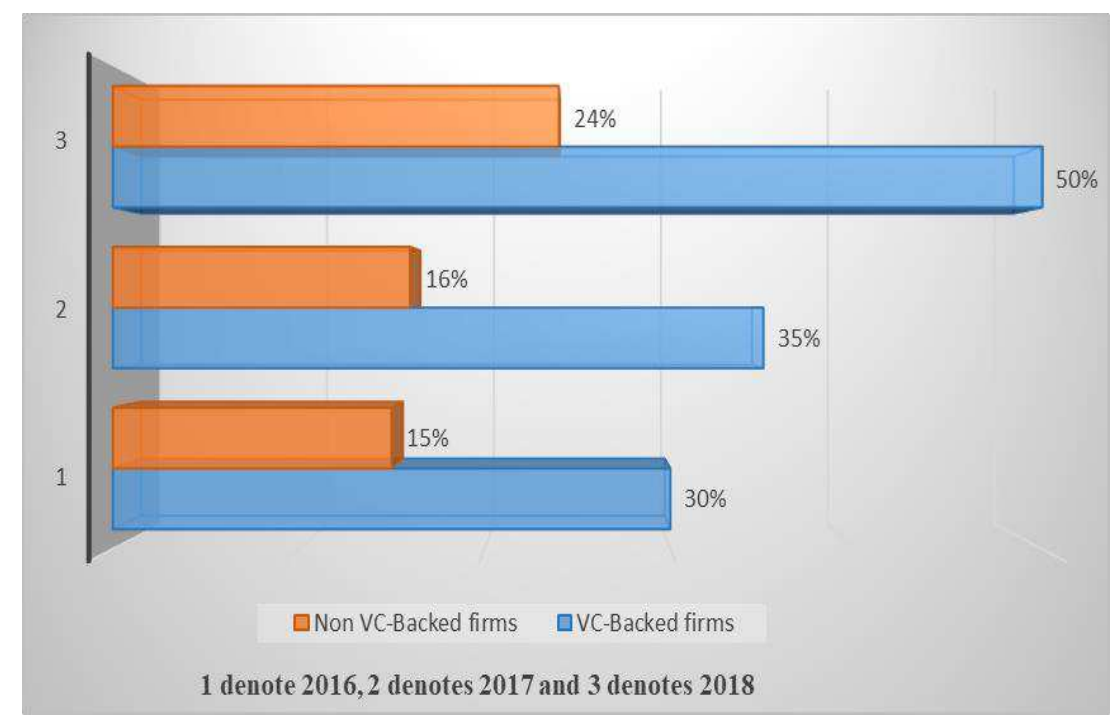

Source (Primary data, 2019-2020).

In Figure 4.1 reveals that the VC-backed firms realized much higher profits between $30 \%-50 \%$ compared to $15 \%-24 \%$ for the non VC- backed industries. The highest profits were reported in 2018 where the VC-backed firms realized $50 \%$ as equated to $24 \%$ for the non VC-backed firms. A company that earns higher profits implies better performance and efficiency compared to its competitors in the same industry. We used EBIT to take care of any tax rates differences charged to the different sectors. Our results certainly confirm that increasing VC financing to the early-stage firms contributes to profitability growth. These results are consistent with the study of (Gompers \& Lerner, 2004; Biney, 2018). Therefore entrepreneurs in need of patient capital to grow their enterprises, VC financing is a suitable alternative to fill the financing gap.

Recent studies suggest the financial stability of a firm is usually assessed by its capacity to generate sufficient profits which enlarges the value of invested capital to meet its financial obligation both in the short and long term (Myskovsa \& Hajek, 2018). Therefore it goes without 
question that the survival and growth of the business are entirely dependent on its capacity to generate sustainable profits (Madura, 2015). Given that the times series data collected for the last three years (2016-2018), it can be expected the results might yield autocorrelation. We run an ANOVA analysis test to establish if there is any relationship between the dependent variable (profitability) and the independent variables (VC finance \& VCs on seats on BOD).

Table 4.2. ANOVA Tests to determine the level of significance between profitability and VC financing

\begin{tabular}{|l|l|l|l|l|l|l|}
\hline \multicolumn{2}{|l|}{ Model } & Sum of Squares & df & Mean Square & F & Sig. \\
\hline 1 & Regression & 6.435 & 3 & 2.145 & 5.536 & $.002^{\mathrm{b}}$ \\
\cline { 2 - 8 } & Residual & 24.800 & 65 & 0.3815 & & \\
\cline { 2 - 7 } & Total & 31.235 & 68 & & & \\
\end{tabular}

a. Dependent Variable: profitability growth

b. a. Predictors: (Constant), VC co-investment, VC leads to SMEs' Growth, VCs direct involvement in management

\section{Source (Primary data, 2019-2020).}

Table 4.2 indicates $\mathrm{F}$ tests $(3,2.145)$ and $\mathrm{P}$-value $=0.02$ which is less than our estimated significance level at .05 . The hypothesis test of $\mathrm{R} 2=0$ yields a $\mathrm{p}$-value of much less than $5 \%$, indicating that significant variability in the profitability is explained by the use of VC finance. This offers irresistible evidence that our model is well fit and valid. As can be seen, the results confirm that VC financing escalates profitability for the funded companies because the regression coefficient is not equal to zero. 
Using the Pearson Correlation Coefficient to determine the relationship between ROA and VC finance.

We run the Pearson correlation tests to determine if there is any relationship between ROA and VC financing as illustrated in Table 4.1 below.

Table 4.1. Pearson Correlation tests between ROA and VC finance

\begin{tabular}{|l|l|l|l|}
\hline \multicolumn{2}{|l|}{ Tests conducted using Pearson Coefficient } & Venture capital & ROA \\
\hline Venture capital & Pearson Correlation & 1 & $.336^{* *}$ \\
\hline & Sig. (2-tailed) & & 0.005 \\
\hline ROA & N & 68 & 68 \\
\cline { 2 - 4 } & Pearson Correlation & $.336^{* *}$ & 1 \\
\cline { 2 - 4 } & Sig. (2-tailed) & 0.005 & 68 \\
\cline { 2 - 4 } & N & 68 & \\
\hline **. Correlation is significant at the 0.01 level (2-tailed). & \\
\hline *. Correlation is significant at the 0.05 level (2-tailed).of (P<0.05). \\
\hline
\end{tabular}

\section{Source (Primary data, 2019-2020).}

Table 4.3 indicates a correlation coefficient of $(\mathrm{r}=0.336, \mathrm{p} \leq 0.05)$ designating that there is a positive relationship since the $\mathrm{p} \leq 0.05$. Correlation is significant when $* \mathrm{p}<0.05$ and our test results are below $\mathrm{p}<0.05$. The results suggest that $33.6 \%(0.336)$ of the changes in ROA can be explained by the use of $\mathrm{VC}$ finance. We can, therefore, conclude that there is a positive relationship between VC financing and ROA. Particularly, firms that received VC financing recognized higher ROA than the non-VC-backed firms. These results are similar to the study of Kwame, (2017). ROA ratio is very essential to the company because it is frequently used to assess the company's financial performance for the different years, or when comparing two different companies of similar size in the same industry. A higher percentage of ROA depicts the good financial performance of the firms in terms of its asset base producing profits with each dollar invested. 


\subsection{Hypothesis 2: Role of VCs on the BOD of the portfolio companies leads}

\section{Enterprises Success.}

We run descriptive statistics to obtain the mean and standard deviation scores to assist in measuring the contribution of the $\mathrm{VCs}$ on the BOD of the portfolio companies in influencing profitability.

Table 4.2. Descriptive statistics for profitability.

\begin{tabular}{|l|l|l|l|}
\hline Variables & $\mathrm{N}-=68$ & Mean & STD \\
\hline Sales revenue & 68 & 3.7 & 0.68279 \\
\hline VCs involvement in management of & 68 & 4.0 & 0.63325 \\
VC-backed firms & & & \\
\hline VC finance increased profitability & 68 & 3.8 & 0.87836 \\
\hline
\end{tabular}

\section{Source; (Primary data, 2019-2020).}

Table 4.4 shows a mean and standard deviation scores of 4.0 and a standard deviation $=0.0633$ respectively. These results demonstrate a positive contribution of the VCs presence on the BOD of the funded companies as the mean score was way above the average score of 3.5 denoted for agreeing and the deviation from the mean 0.633 is insignificant. These results are strengthened by the questionnaire response rate of $68 \%$ (46 of 68) of the respondents who attested that the VC-backed firms registered increased profits after VC financing. We asked the respondents if they recognised improved sales turnover after VC investment. The descriptive results indicated a mean score of 3.8 and a standard deviation of 0.07836 . These results confirms that VC financing leads to increased sales revenue. 


\subsection{Face-to-face interview Results}

The study performed 16 face-to-face interviews which brought together the view of all the stakeholders in the VC industry including management staff, VCs/Business Angels, government agency, and SMEs' Associations as shown in Table 4.4 below.

\begin{tabular}{|c|c|c|c|}
\hline Category of Respondents & Sample Size & Actual Response & Response rate \\
\hline SMEs' Management Staffs & 20 & 7 & $23.3 \%$ \\
\hline VCs/Business Angels & 6 & 6 & $20.0 \%$ \\
\hline Government Bodies & 2 & 1 & $3.3 \%$ \\
\hline SMEs' Umbrella Associations & 2 & 2 & $6.7 \%$ \\
\hline Total & 30 & 16 & $53.3 \%$ \\
\hline
\end{tabular}

Source: (Primary data, 2019-2020).

Table 4.4 reveal a response rate of $53.3 \%$ of face-to-face interviews performed with the VC stakeholders. Management staff constituted 23\%, followed by VC firms/business angels as these form the foundation of the $\mathrm{VC}$ market, and government plays the role of creating a supportive business environment while SME associations advocate for their business privileges. We run a content analysis using Atlas-ti until the point of saturation was attained at the $16^{\text {th }}$ interviewee. Sunders et al., (2009) argues that the level saturation is grasped when the interviewer continues to get similar results not different from the earlier responses. It is important to state that the 16 interviews were therefore sufficient for the study.

We carried out face-to-face interviews with the respondents to determine whether the VCfinanced companies realised higher profits subsequent to $\mathrm{VC}$ financing. More attentiongrabbing results were from the fund managers who emphasized that "To maximize profits, it is 
mostly about structuring not having a routine or monthly payments, this is the real framework that enhances profitability. Our profitability growth of the funded companies is, about $50 \%$ of the projects are doing very well, $30 \%$ are struggling and $20 \%$ of the projects completely fail" These results demonstrate that $\mathrm{VC}$ financing is a precursor to profitability growth which eventually encourages growth of the early- stage enterprises. We also discover early-stage firms that can demonstrate the capacity to generate worthy profits have higher chances of attracting VC financing (Myskova \& Hajek, 2017).

Our interview face-to-face interviews on the question of if the presence of the VCs on the BOD of the VC-backed firms escalates their growth, disclosed $69 \%$ of the respondents confirmed enhanced growth of VC-backed companies arising from the superior skills of the VCs. This was manifested in access to new market, financial management skills, innovations and expanding networks to other investors. Interesting to report, one of the interviewees DRSO5 stated that the rigorous due diligence alone is enough to encourage the growth of the business even if VCs is not provide patient capital." Another respondent DRS05 commented that the VCs involvement on the BOD level assisted to quickly discover any financial hurdles, they deliver technical advice to mitigate the financial risks at an early-stage "The VCs monitoring of the portfolio companies tends to reduce if the funded firms demonstrate sound and lucrative performance.

Besides, our findings disclose that VCs do not only offer patient capital, but there is a noticeable value add to the investee companies manifested in the VCs motoring exercises, facilitating access to international markets, coaching in financial management, and delivering hands-on assistance to the portfolio companies. This conforms to earlier scholars who contended that 
value addition to the portfolio companies is essential for $\mathrm{VC}$ investment because it differentiates it from other sources of funds (Lerner, 2010; Hellmann \& Puri, 2002).

We also asked the interviewee to determine whether there was increased growth in returns on equity of the VC-backed firms after VC financing. Whereas most of the financing was expansion funding, the interviewees reported $25-35 \%$ average increase in returns. It is also important to say that these figures are not constant since they invest in a high-risk sector. One the fund manager emphasized "It is also important to say that PE/VC as a patient capital is there to partner with business owners and help them grow. We are not only there to bring the cash on the table, but we also bring bigger networks to talents to help these companies grow, we bring experience from other markets in terms of how we scale businesses" The results were similar to the findings of (Lerner, 2010; Arundale, 2018). All these results highlight the significance of VCs' role on the BOD of portfolio companies leading to profitability growth.

Despite the appealing results, VCs encounter problems to which may undermine the success and growth of the early stage firms. One of the VCs stated "One channel of exiting is when we come out of the business and we are ready to sell our stake, either to the business owners or to the equity market where there is an opportunity to list on the stock market, for which there has not been a great channel. But if there is an opportunity to list, we may monitor to see when the best time to bring that exit to the IPOs but that has not been the case so far" The point to make here is that VCs find it difficult to exit through IPOs or trade sale due to the undeveloped financial market in Uganda which may adversely impact the returns on capital. In addition, we discovered presence of VC myopia as the entrepreneurs/managers fear losing control of their companies arising from the temporal sharing of ownership. This partially explains the gradual uptake of VC investment in Uganda. Therefore some business entrepreneurs remain sceptical 
to enter into VC deals because they do not know their destiny. This conforms to the conclusions made by Tykvova, 2018.

\section{Practical implications and limitations}

This is the first-time comprehensive study which conveys an integrated thoughts of all key VC market stakeholders where the views of the VC experts are complemented with those of the other stakeholders. The current study presents appealing empirical results that confirm evidence of the impact of VC financing on the profitability of the SMEs' in Uganda. Where earlier studies present an enthralling picture to academia as if all VC-funded companies are profitable and attract good returns, this paper discovered that only $50 \%$ of the $\mathrm{VC}$ - backed companies were exceedingly operating as expected, $30 \%$ were struggling and $20 \%$ completely failed. These results are consistent with the study of HIS Global insight, (2008).

Additionally, the study was confined to agribusiness and manufacturing SMEs in Uganda stratified from CBD comprising Kampala, Wakiso, Mukono, and Jinja districts. As such the results may be different from SMEs located in the rural settings characterised by poor infrastructural development. Therefore the results ought to be used with caution as they may yield subjective results in the different sectors like Fintech industries, and generally the service sector.

\section{Contribution to knowledge}

This study makes a vital contribution to novel knowledge by offering a diversified framework for Enterprise success (Figure 6.1). This framework is recommended to benefit the key players in the $\mathrm{VC}$ market in manipulating VC financing to enhance Enterprise success. Although VC has been extensively studied, no study has developed a diversified framework for Enterprise success (Figure 6.1) that integrates exclusive performance variables like VC finance, 
government involvement, and human capital and credible business plans to assess enterprise success. Our study findings reveal that these variables significantly impact enterprise success, this motivated the authors to develop a diversified framework for enterprise success that takes into account these variables which have not been yet used in prior literature.

According to the framework (Figure 6.1), the interaction of $\mathrm{VC}$ finance, government involvement, credible business plans, and human capital, was proved indispensable in enhancing Enterprise success. First, government involvement in the VC market is essential for making supportive regulations and enhancing Co-investment funds into private equity firms. Secondly, VC finance was identified as a significant variable for stimulating enterprise's success matched to conventional bank lending. Thirdly, the credible business plans for potential entrepreneurs, is a turning point for SMEs' success. These performance variables are supported by evidence from semi-structured Interviews (section, 4.2) that disclosed that $2 \%$ out 100 business plans pass the due diligence process to qualify for VC financing. Finally, human capital encompassing VCs on the BOD and senior management, were identified as very instrumental variables in encouraging enterprises success. This framework is reinforced with our empirical evidence from the quantitative results and face-to-face interview results (section $4.1 \& 4.2)$. Therefore, the interaction of all these variables as illustrated in Figure: 6.1 translates into enterprise success manifested in improved profitability, good ROE, ROA and sales turnover. For that reason developing a diversified framework for enterprise success was necessary to assist the VC stakeholders in measuring enterprise success.

To the best of our knowledge, no previous study has ever applied this set of integrated variables to examine the performance of SMEs. On this basis, this framework was necessary to contribute to the body of knowledge and also pave away for future investigation. To improve the framework, the study suggests future research to investigate 
"To what extent do government involvement in VC financing, the entrepreneurs' credible business plans and the presence of the venture capitalists on the BOD may enhance early-stage Enterprise success in Uganda?”

\section{Figure 6. 1 Diversified Framework for Enterprise Success}

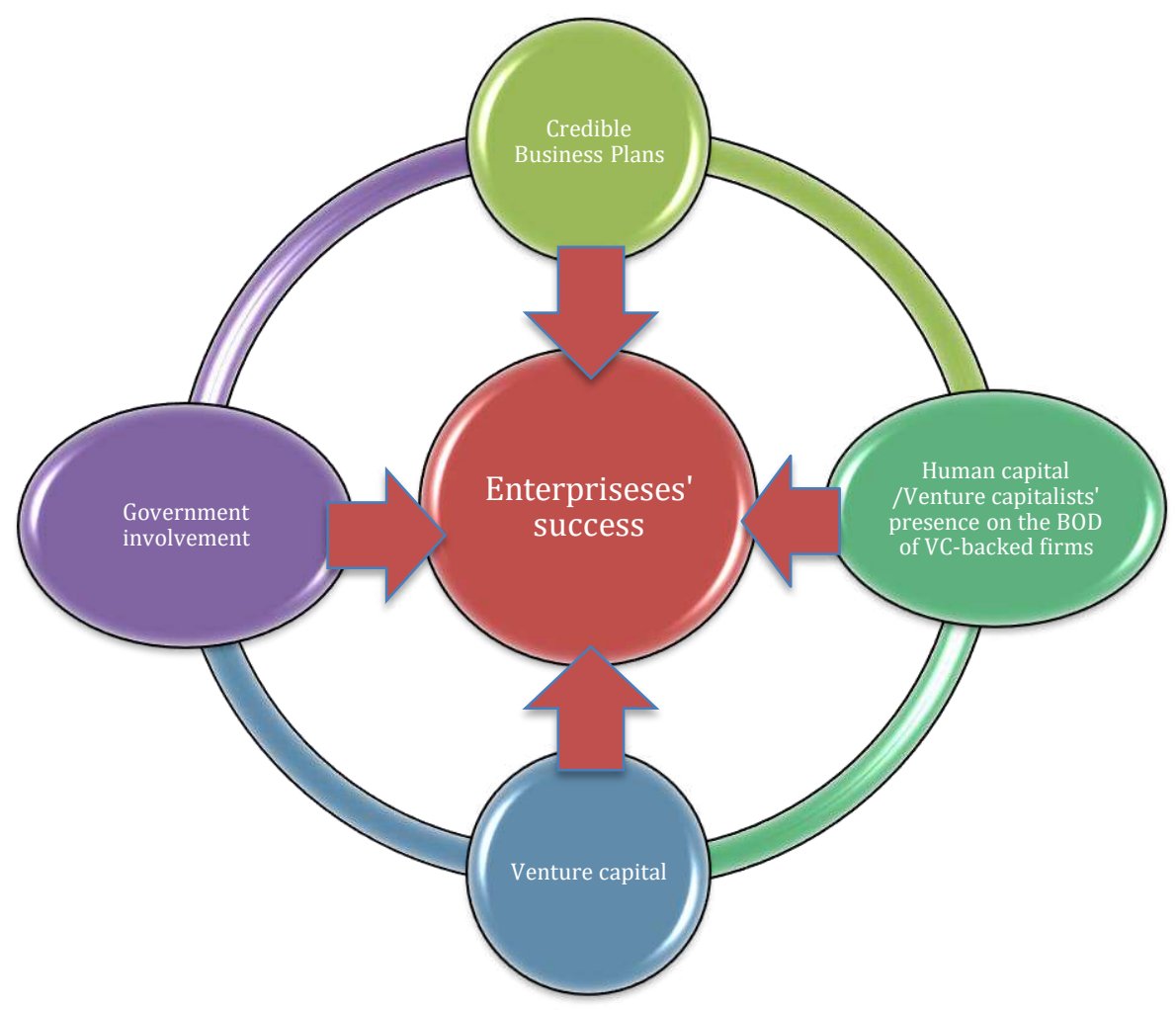

Source: Author's contribution to knowledge: A Diversified Framework for Enterprise Success

\section{Conclusion and future research directions}

This paper uncovers that VC financing is connected with quicker firm's growth and a precursor for profitability of the early-stage enterprises. The VC-financed enterprises reported superior performance displayed in improved profitability between $30 \%-50 \%$ as matched to $15 \%-24 \%$ for the non VC- financed companies, Sales revenue enlarged by $33.6 \%$ and Returns on Assets value-added by $44.5 \%$. A higher financial percentage, conveys commendable performance that underwrites the success and growth of an enterprise. These results are consistent with the findings of (Biney, 2018; Kenawy and Ghany, 2012). In addition, our findings expose disclosed $69 \%$ of the respondents confirmed enhanced growth of VC-backed companies arising from 
the superior skills of the VCs. On this basis, increasing VC investment in Uganda and similar emerging economies would assist to close the financing gap which inhibits the success and growth of the small-medium enterprises. Because private VC companies come along with new technology which the local companies do not have, they increase VC investment and permit the entrepreneurs/managers to shift their financial risk in the case of business failure to the VC firm.

Whereas VC financing appears exciting and widely accepted to spur enterprise success and growth, a handful of studies have examined the impact of VC financing on enterprise success and growth. Therefore, future investigations in this area would complement this study and improve on the diversified framework for enterprise success.

\section{Declarations of Interests:}

Availability of data and materials Statement: The datasets generated and/or analysed during the current study are not publicly available due to the Non-Disclosure agreements we signed with the respondents but are available from the corresponding author on reasonable request.

Competing interests: The authors declare that they have no known competing financial interests or personal relationships that could have appeared to influence the work reported in this paper.

Funding: This study did not receive any funding

Authors' contributions: Ahmed .I. Kato is the focal author of this article and Prof ChiloanePhetla .E. Germinah is a co- author, who contributed technically as an advisor toward improving the article.

Acknowledgements: Special thanks to the college of Economic and Managements for the financial support.

Authors' information (optional) 
1. Ahmed. I. Kato’ PhD Researcher’ Department of Applied Management University of South Africa, Pretoria’ Email: ahmedkato2@gmail. Corresponding Author:

2. Prof Chiloane-Phetla E. Germinah’ Entrepreneurship M\&D Coordinator Research Department of Applied Management' University of South Africa, Pretoria Email:chiloge@unisa.ac.za, Co-Author.

\section{Reference List}

Arundale, K. (2018) "Exploring the difference in performance between UK/European venture capital funds and US venture capital funds.” Available at: http://theses.gla.ac.uk/30827/1/2018ArundalePhd.pdf.

Ayyagari, M., Demirguc-Kunt, A. and Maksimovic, V. (2011) 'Small vs. young firms across the world: contribution to employment, job creation, and growth', World Bank Policy Research Working Paper Series, (April), pp. 1-57. doi: 0.1596/1813-9450-5631.

Baldock, R. and North, D. (2015) 'The role of UK government hybrid venture capital funds in addressing the finance gap facing innovative SMEs in the post-2007 financial crisis-era' Research Handbook on Entrepreneurial Finance, pp. 125-146. doi: $10.4337 / 9781783478798.00014$.

Beck, T. \& Cull, R. (2014) 'Small and medium-sized enterprise finance in Africa. African Growth Initiative' (working paper 16)', Washington, DC: Brookings'.

Berger, A. N., \& Udell, G. F. (1998) 'The economics of small business finance. The roles of private equity and debt markets in the financial growth cycle' Journal of Banking \& Finance, 22(6), 613- 673

Bertoni, F. and Tykvová, T. (2015) ‘Does governmental venture capital spur invention and innovation? Evidence from young European biotech companies’ Research Policy. North-Holland,44(4), pp. 925-935. 
Bertoni, F., Colombo, M. G., \& Quas, A. (2015) 'The patterns of venture capital investment in Europe' Small Business Economics, 45(3), 543-560.

Bertoni. F, Massimo G. Colombo, and Luca Grilli. (2018) 'Venture Capital Financing and the Growth of New Technology-Based Firms: A Longitudinal Analysis.

Biney, C. (2018) 'The Impact of Venture Capital Financing on SMEs' Growth and Development in Ghana’ Bus Eco J 9: 370. DOI: 10.4172/2151-6219.1000370.

Bocken, N. M. P. (2015) 'Sustainable venture capital e catalyst for sustainable start-up success?' Journal of Cleaner Production. Elsevier Ltd, 108, pp. 647-658. doi: 10.1016/j.jclepro.2015.05.079.

Bocken, N. M. P. (2015) 'Sustainable venture capital e catalyst for sustainable start-up success?' Journal of Cleaner Production. Elsevier Ltd, 108, pp. 647-658. doi: 10.1016/j.jclepro.2015.05.079.

Bottazzi, L., M. Da Rin, and T. Hellmann (2008). "Who are the active investors? Evidence from venture capital". Journal of Financial Economics. 89(3): 488-512.

Carvalho, A. G.; Netto, H. G.; Sampaio, J. O. (2013) 'Conducted as research on Private Equity and Venture Capital in Brazil analyzing its Recent Evolution' Available at SSRN: http://papers.ssrn.com/sol3/papers.cfm?abstract_id=1996729. Brazil.

Chemmanur, T. J., Krishnan, K. and Nandi, D. K. (2011) 'How does venture capital financing improve efficiency in private firms? A look beneath the surface' Review of Financial Studies, 24(12), pp. 4037-4090. doi: 10.1093/rfs/hhr096.

Collis, J., and Hussey, R. (2009) 'Business Research: A Practical Guide for Undergraduate and Postgraduate Students' 3rd Edition. Basingstoke: Palgrave Macmillan.

Creswell J. W. (2003) 'Qualitative, Quantitative, and Mixed Methods Approaches' Thousand Oaks, CA: Sage. 
Creswell, J.W., and Plano-Clark, V.L. (2010) 'Designing and Conducting Mixed Methods Research' Thousand Oaks, C.A: Sage.

Cumming, D., \& Johan, S. (2016) 'Venture's economic impact in Australia' Journal of Technology Transfer, 41(1), 25-59

Cumming, D.J. \& Johan, S.A. (2009) 'Venture capital and private equity contracting: An international perspective'. Amsterdam: Elsevier Science Academic Press.

Cumming, D.J., Grilli, L., Murtinu, S. (2013) 'Governmental and Independent Venture Capital Investments in Europe. A Firm-level Performance Analysis' Available at SSRN: http://ssrn.com/abstract=2294746.

Deloitte \& NVCA. (2009) 'Global Economic Downturn Driving Evolution of Venture Capital Industry, According to Study by Deloitte and National Venture Capital Association [News Release].

Divakaran. Mcginnis and M. Shariff. (2016) "Ghana Private Equity and Venture Capital Ecosystem Study" (2016) Ghana Private Equity and Venture Capital Ecosystem Study, (October). doi: $10.1596 / 30165$.

Eniola, A. A., \& Ektebang, H. (2014) 'SME firms' performance in Nigeria: Competitive advantage and its impact' International Journal of Research Studies in Management, 3(2), 75-86.

Ernst and Young. (2016) 'Back to reality, EY global venture capital trends 2015' from (online) www.ey.com/Publication/vwLUAssets/ey-global-venture-capital-trends2015/EY-global venture-capital-trends-2015.pdf (Accessed, 30.07.2019).

Esho.E and Verhoef.G, (2018) 'The Funding Gap and the Financing of Small and Medium Businesses: An Integrated Literature Review and an Agenda. MPRA Paper No. 90153 posted.

EU/OECD. (2016) 'Policy Brief on Scaling the Impact of Social Enterprises' European Union and OECD, http://www.oecd.org/cfe/leed/Policy-brief-Scaling-up-social-enterprises-EN.pdf. 
Gompers, P., \& Lerner, J. (2001) 'The venture capital revolution' Journal of Economic Perspectives, $15(2), 145-168$

Gompers, P., and Lerner. P (1998) 'What Drives Venture Capital Fundraising?' Brookings Papers on Economic Activity - Microeconomics. Brookings Institution: Washington, D.C.

Gompers, P., Gornall, W., Kaplan, S., \& Strebulaev, A. (2020) 'How do venture capitalists make decisions? Journal of Financial Economics. 135 (2020) 169-190.

Hellmann, T. \& Puri, M. (2002)' Venture capital and the professionalization of startup firms: Empirical evidence' The Journal of Finance, 57(1), 169-197

Hirukawa, M. \& Ueda, M. (2008) 'Venture capital and industrial innovation, CEPR Discussion Paper 7089.

IHS Global Insight, (2008), Venture Capital 'The Economic Importance of Venture Capital-Backed Companies to the U.S. Economy' $5^{\text {th }}$ Edition California US 'visit www.ihsglobalinsight.com

Jain, B. and Kini, O. (1995) 'Venture capitalist participation and the post-issue operation performance of IPO firms’ J Managerial and Decision Economics 1995, 16:593-606.

Kelly, R., \& Hankook, K. (2013). Venture Capital as a Catalyst for High Growth. http://www.ic.gc.ca/eic/site/eas-aes.nsf/eng/h_ra02218.html, Ottawa: Industry Canada.

Kenawy, E. M. and Ghany, M. F. A. (2012) 'The Economic Importance of Venture Capital as New Funding Alternative with Reference to the Egyptian Experience' 2(4), pp. 3598-3606.

Kwame, E.B. (2017) 'Assessing the Impact of Venture Capital Financing on Growth of SMEs'. Texila International Journal of Management Volume 3, Issue 2, Nov 2017.

Lerner, J. (2010) 'The future of public efforts to boost entrepreneurship and venture capital' Small Business Economics, 35(3), 255-264.

Li Y, Zahra S (2012) Formal institutions, culture, and venture capital activity: a cross-country analysis. J Bus Venture 27:95-111

Madura, J (2015). Financial Markets and Institutions (11th Ed.) Stanford: Cengage Learning 
Mason, C.M. (2009) 'Public policy support for the informal venture capital market in Europe' A critical review’, Int Small Bus J 27, 536-556.

Metrick, A. and Yasuda, A. (2010), Venture Capital and the Finance of Innovation, John Wiley and Sons.

Munari, F., \& Toschi, L. (2015) 'assessing the impact of public venture capital programs in the United Kingdom: Do regional characteristics matter?' Journal of Business Venturing, 30(2), 205-226.

Murray, G. C. (2007) 'Venture Capital and Government Policy. In Handbook of Research on Venture Capital, edited by H. Landstrom, 113-151. Cheltenham: Edward Elgar.

NVCA (National Venture Capital Association) (2011), National Venture Capital Association Yearbook, A Report Prepared by Thomson Reuters for National Venture Capital Association. Puri, M. and Zarutskie, R.,(2012) 'On the lifecycle dynamics of venture capital and non-venture capital financed firms' Journal of Finance, Vol. 67, Issue 6, pp. 2247-2293.

Rosenbusch N, Brinckmann J, Müller V (2012) 'Does acquiring venture capital pay off for the funded firms? A meta-analysis on the relationship between venture capital investment and funded firm financial performance. J Bus Venture 28:335-353

Saunders, M., Lewis, P. and Thornhill, A. (2009) 'Research methods for business students' 5th Edition. London: Pearson Hall Limited.

Saunders, M., Lewis, P., and Thornhill, A., (2012) 'Research Methods for Business Students' Pearson Education Ltd., Harlow.

Serrasqueiro, Z., Nunes, P. M., \& Armada, M. R. (2016) 'Capital structure decisions: Old issues, new insights from high-tech small and medium-sized enterprises’ European Journal of Finance, 22, 59-79. doi:10.1080/1351847X.2014.946068.

Shanthi.D, McGinnis.P, Schneider.S, (2018) 'Survey of the Kenyan Private Equity and Venture Capital Landscape1 Authors: Policy Research Working Paper 8598. World Bank Group. Finance, Competitiveness and Innovation Global Practice October 2018. 
Turyahikayo, E. (2015) 'Challenges Faced By Small and Medium Enterprises in Raising Finance In Uganda' International Journal of Public Administration and Management Research (IJPAMR), 3(2), pp. 21-33. Available at: http://www.rcmss.com.

Uganda Investment Authority. (2016) 'Private Equity, and Venture Capital Conference 2016. Serena Kampala Uganda

Zhang, T, Chen X, Huang J. (2015) 'Political connection, venture capital investment, and firm performance' Review of Nankai Business Review 2015, 18(5):18-27. 


\section{Figures}

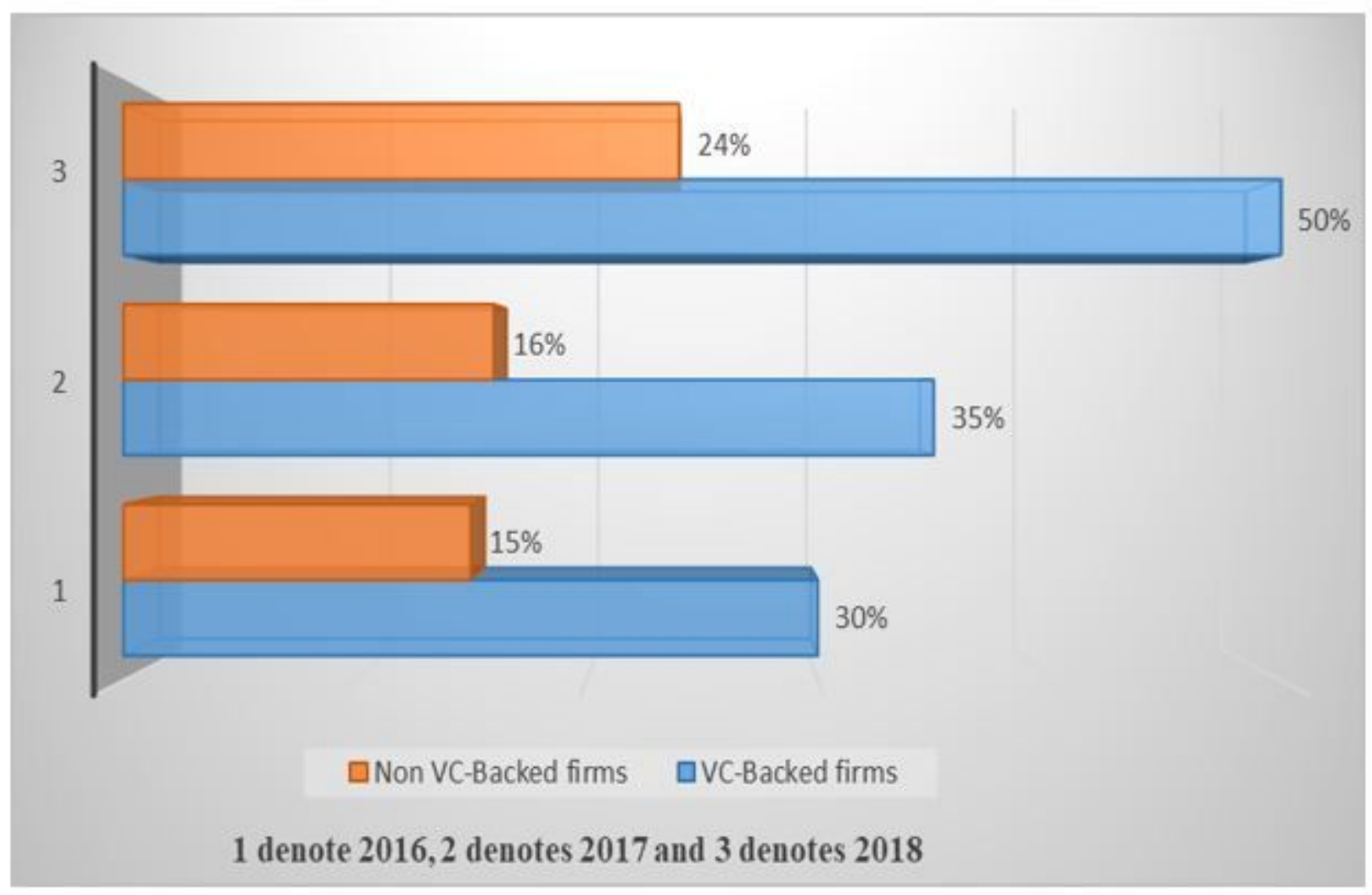

\section{Source (Primary data, 2019-2020).}

\section{Figure 1}

Comparison of Profits before Interest and Tax for the VC -backed and non VC-backed firms from 2016 to 2018. 


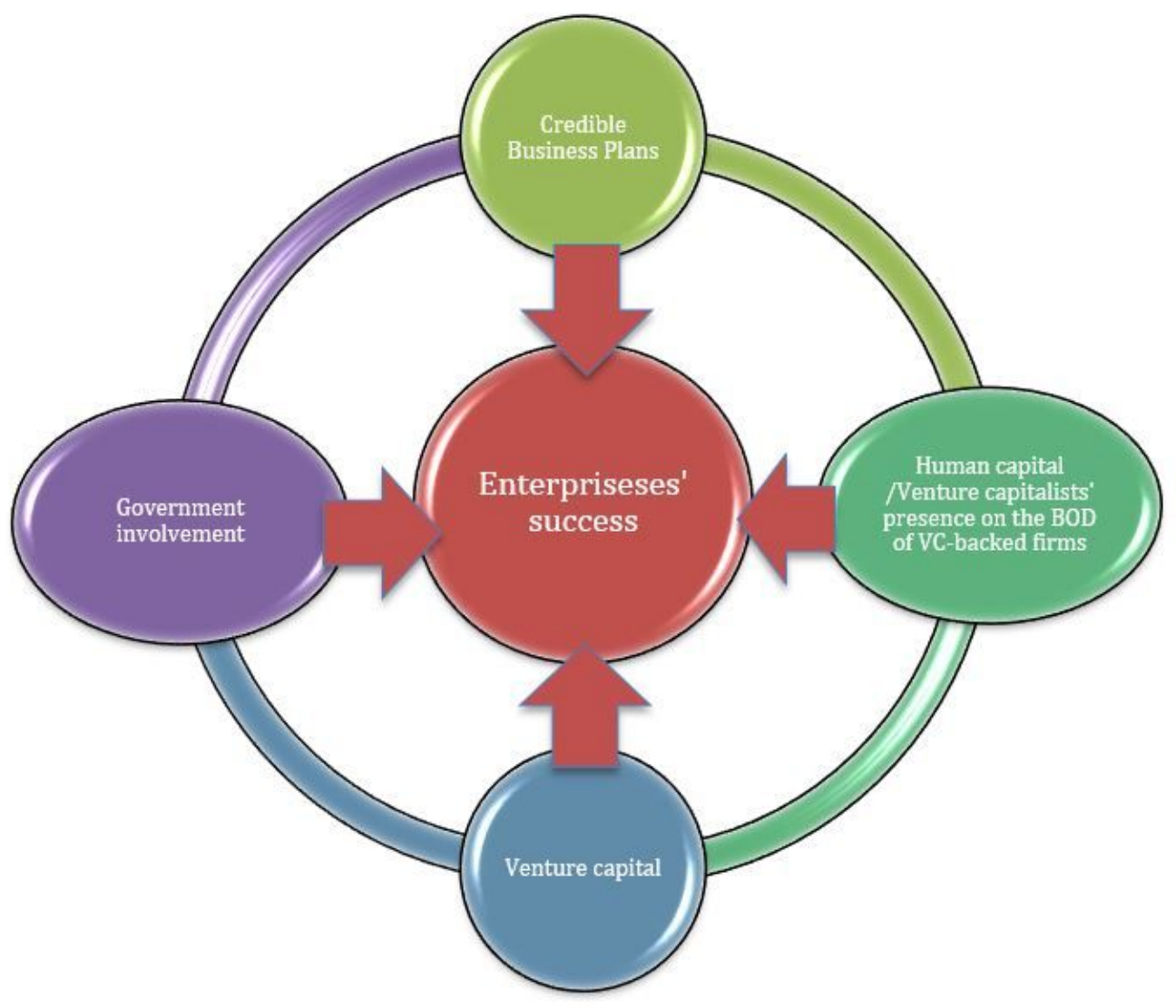

Source: Author's contribution to knowledge: A Dikersified Framework for Enterprise Success

Figure 2

Diversified Framework for Enterprise Success 